Anatomy" gained him a lasting reputation. Within the field of medicine he was noted for his work on tuberculosis ; he considered bronchitis to be a contributory factor in the causation of the disease and was an early advocate of open-air treatment. His book, "Illustrations of Pulmonary Consumption", was published in 1834. Morton also made notable contributions to geology, zoology and vertebrate palæontology. His "Synopsis of the Organic Remains of the Cretaceous Group of the United States" (1834) described fossils brought back by the Lewis and Clark Expedition and may be considered the starting point of palieontological and systematic work on American fossils. An earlier work dealt with numerous fossil forms-plesiosaurs, crocodiles, horses, elephants and mastodons-found near the Rariton River, New Jersey. For purposes of comparative study he assembled a large series of human skulls; the collection was said to have cost him between ten and fifteen thousand dollars, and to be "worth a visit to America". For his conclusion that the races of man were of diverse origin he was bitterly assailed by many who claimed that he was denying the authority of the Scriptures.

\section{History of Sources of Energy}

THE latest science pamphlet in the fortnightly series published by the Bureau of Current Affairs has been written by William E. Dick, the editor of Discovery, and describes the development of sources of energy from early times. Beginning with the use of man's own energy, Dick examines the employment of animals, wind and water mills, steam and iron, the development of railways and ships, the growth of electricity and the origin of the steam turbine and the internal combustion engine, the first aircraft, and the invention of the gas turbine. Water and tidal power, the wind, heat of the sea, geothermal and solar energy are discussed as other possible sources of power, while, in another section, the author discusses the efficient use of fuel before examining the source and potentialities of atomic power. Like the majority of these pamphlets, "The Story of Energy" is admirably illustrated with attractive and topical diagrams and illustrative charts and maps. It also contains a lucid summary and relevant bibliography.

\section{Royal Commission on University Education in Dundee}

A Royal Commission has been set up to inquire into the organization of university education in Dundee. Its terms of reference are: "To inquire into the organization of university education in Dundee and its relationship with St. Andrews University, and to recornmend. what changes, if any, should be made in the constitution, functions, and powers of the University of St. Andrews, of University College, Dundee, or of any other body or institution concerned". The Commission consists of Lord Tedder (chairman), Lord Greenhill, Sir David Lindsay Keir, Prof. Dugald Baird, Mr. David Emrys Evans, Mrs. Isabel Finlayson, Prof. H. W. Melville, Mr. J. S. Muirhead and Mr. Andrew Robertson. The secretary of the commission is Mr. N. J. P. Hutchison, of the Scottish Home Department; communications should be addressed to him at the office of the Royal Commission, 12 Carlton Terrace, Edinburgh, 7.

\section{Royal Geographical Society: Awards}

THE King has approved the following awards of the Royal Medals of the Royal Geographical Society:
Founder's Medal to Dr. V. E. Fuchs, principal scien. tific officer, Falkland Islands Dependencies Survey scientific bureau, Colonial Office, for his contributions to Antaretic exploration and research as leader of the Survey, 1948-50; Patron's Medal to Dr. Donald Thomson, research fellow, University of Melbourne, for geographical exploration and studies in Arnhem Land.

The Council has made the following awards: Victoria Medal to Dr. C. A. Cotton, professor of geology, Victoria University College, New Zealand, for his contributions to the geomorphology of New Zealand; Murchison Grant to Dr. George Salt, Fellow of King's College, Cambridge, for geographical studies of the Shira Plateau of Kilimanjaro; Back Grant to Mr. J. N. Jennings, lecturer in geography, University College, Leicester, for his work on the origins of the Broads; Cuthbert Peak Grant to Mr. W. B. Harland, lecturer in geology, University of Cambridge, for surveys and mapping in central West Spitsbergen; Gill Memorial to Dr. W. R. Mead, lecturer in geography, University College, London, for geographical research in Finland.

\section{Institution of Mining and Metallurgy: Awards}

THE Institution of Mining and Metallurgy has announced the following awards : Honorary Membership of the Institution: Sir Henry Tizard, in recognition of his outstanding services to science, industry and education; and Sir Andrew Bryan, H.M. chief inspector of mines, in recognition of his distinguished services to the mining industry of the United Kingdom. Consolidated Gold Fields of South Africa, Limited, Gold Medal for 1950, jointly to J. P. Norrie and W. T. Pettijohn for their paper on "An Outline of Underground Operations at Mufulira Copper Mines, Ltd." (Trans., 59). Consolidated Gold Fields of South Africa, Limited, Premium (forty guineas) for 1950, jointly to H. L. Talbot and H. N. Hepker for their paper on "Investigations on the Production of Electrolytic Cobalt from a Copper-Cobalt Flotation Concentrate" (Trans., 59). William Frecheville Students' Prize to G. J. Mortimer for his paper on "Grade Control" (Trans., 59).

\section{Iron and Steel Institute : Medals and Prizes}

Ter following Medals and Prizes of the Iron and Steel Institute have recently been awarded : Bessemer Medal for 1951 to Benjamin Fairless, president of the United States Steel Corporation, in recognition of his distinguished services to the iron and steel industry; Sir Robert Hadfield Medal for 1951 to William Barr for his contributions to research in steelmaking; Andrew Carnegie Silver Medal for 1950 to A. B. Winterbottom for his report on "Optical Studies of the Oxidation of Iron at Temperatures in the Range 20-265 C." ; Williams Prize for 1950 jointly to T. H. Harris and W. H. Everard for their paper on "The Use of the Oxygen Lance in British Electric Furnace Practice" (their co-author, D. J. O. Brandt, is not eligible to participate in the Prize); Ablett Prize for 1950 jointly to D. A. Wise and Dr. L. N. Bramley, for their paper on "Proposed Method of Specifying TravelMotion Performance for Steelworks Overhead Cranes".

\section{Royal Institution: Officers}

AT the anniversary meeting of the members of the Royal Institution, held on May 1, the following officers were elected: President, Lord Brabazon of Tara; Secretary, Prof. A. O. Rankine; Treasurer, Dr. R. E. Slade; Managers, Dr. P. Dunsheath, Sir 